\title{
OPEN
}

Published online: 31 December 2019

\section{Publisher Correction: Self- harm behaviour and externally- directed aggression in psychiatric outpatients: a multicentre, prospective study (viormed-2 study)}

\begin{abstract}
Paolo Scocco, Ambra Macis, Clarissa Ferrari Dattia Bava, Giorgio Bianconi, Viola Bulgari, Valentina Candini, Giuseppe Carrà, Cesare Cavalera, Massimo Clerici, Giovanni Conte, Marta Cricelli, Maria Teresa Ferla, Laura lozzino, Alberto Stefana $(D)$ \& Giovanni de Girolamo $\mathbb{D}$

Correction to: Scientific Reports https://doi.org/10.1038/s41598-019-53993-7, published online 28 November 2019
\end{abstract}

The original version of this Article contained errors. In the title of the paper, the word "in" was incorrectly given as "In".

In the original Table 1, cells in column six were not merged correctly and the table has been replaced.

Finally, the original Figures 1 and 2 have been replaced with higher resolution images.

These errors have now been corrected in the PDF and HTML versions of the Article. The accompanying Supplementary Information file was correct at the time of publication.

(c) (i) Open Access This article is licensed under a Creative Commons Attribution 4.0 International (c) License, which permits use, sharing, adaptation, distribution and reproduction in any medium or format, as long as you give appropriate credit to the original author(s) and the source, provide a link to the Creative Commons license, and indicate if changes were made. The images or other third party material in this article are included in the article's Creative Commons license, unless indicated otherwise in a credit line to the material. If material is not included in the article's Creative Commons license and your intended use is not permitted by statutory regulation or exceeds the permitted use, you will need to obtain permission directly from the copyright holder. To view a copy of this license, visit http://creativecommons.org/licenses/by/4.0/.

(c) The Author(s) 2019 